\title{
ASSESMENT OF ECONOMIC EFFECTS OF MOSCOW PROGRAMME OF RENOVATION
}

\author{
Elizaveta Kheifetz \\ Financial University under the Government of the Russian Federation
}

\begin{abstract}
Renovation is seen in the context of an urbanist as a form of large-scale dispersed urban space reorganization. To date, in countries with developed economies, the share of renovation works has increased in the structure of construction from $35 \%$ to $60 \%$.

In this article, the content of the main stages of renovation is detailed: the definition of the scope, planning, financing and implementation. Reflects the experience and tasks of the Moscow Government on the renovation of the quarters of the existing buildings. Since the city renovation projects are aimed at achieving the optimal combination of social, residential and commercial functions, the complex reconstruction of the city has noneconomic and economic effects. Varying the key parameters influences the calculation of the project economy. The most economical indicators of the project depend on the coefficients of renovation and relocation, the cost of construction and the price of sales. To increase the additions in Moscow budget and other economic effects from the project implementation, it is necessary to increase the renovation ratio and the selling price and / or reduce the construction cost and resettlement ratio.
\end{abstract}

Key words: Moscow urban economics, Moscow renovation, Moscow redevelopment

\section{Introduction}

Renovation of the existing buildings is one of the most important town-planning tasks, connected with large-scale changes in the field of urban planning. Any metropolis is faced with the accumulating need to update the territories, infrastructure, architecture, urban systems. According to a study by international consulting company McKinsey, in the world about 330 million urban households live in unfavorable housing conditions or are in so financially distressed circumstances because of spending on housing that they are forced to deny themselves basic needs (Woetzel, 2014). Global renovation projects are increasingly becoming the engine of urban development around the world.

The preservation of the balance of historical heritage and the opportunity to move further in its development is the most important task facing the city authorities in the run-up to the implementation of the renovation program, one of the most socially and economically significant in housing construction.

The Moscow government is implementing a program for the resettlement and demolition of five-story houses "Demolished" series in the last 20 years. The unique experience of resettlement of inhabitants and demolition of houses is accumulated. In total, 5177 residential houses (c. 18 million sqm) were included in the renovation program of the "demolished" series. The current program will start in 2018. However, the bulk of the housing stock, built in the 1950s and 1960s, is still problematic at present. In Moscow, the majority of the five-story buildings of the industrial period of housing construction are morally and physically obsolete: collapsing foundations, divergent joints of wall panels, worn out engineering communications, irreparable repairs, and failed heating systems. Such houses have substantial actual wear (most - more than 40\%), as well as they are morally obsolete (small kitchens, no lift, not adapted for low mobility groups, etc.). Major repairs for most of these houses are inexpedient. Moreover, overhaul is a temporary measure that does not improve the quality of housing. Residential quarters, designed 40-50 years ago, do not meet modern requirements for effective use of urban areas and comfortable living of citizens.

The scale of the renovation program for the dilapidated housing stock in Moscow assumes the demolition of 5,177 houses from the 1950 s to the 1960 s (16.1 million square meters), the resettlement of 1 million inhabitants and the erection of about 30.0 million square meters of new housing. This project covers more than 7\% of Moscow's housing stock and can become one of the most ambitious renovation projects in the world. In addition to solving the "housing issue", the program is designed to 
ensure the complexity of development, to implement new principles of integrated improvement and operation of the urban environment.

Organizationally, the renovation in the blocks of existing buildings is a "Wave" process: first start homes are erected, then resettlement of residents of demolished houses is carried out, demolition and new construction are carried out on the vacated sites. At the same time, some apartments in new houses are used for resettlement, and the rest is sold on the market over time.

Experts examining the issues of urban renewal highlight four key stages in the framework of renovation projects: the definition of scope, planning, financing and implementation. Each stage includes a set of unique tools that local authorities can use for system planning and management of the renovation process. In addition to the four stages, the three main objects involved in the project are identified: land, community and the environment.

The definition of the scope of change corresponds to the evaluation stage. The process of urban reorganization, both for the city as a whole and for a specific land area, begins with a comprehensive assessment of the current situation and the development of strategic decisions (Kievskiy, Grishutin, Kievskiy, 2017). At this stage, an analytical foundation is laid, tooling is formed and the parties involved in the project are identified. There is a perspective evaluation and goal setting, as well as a retrospective analysis that takes into account the history of the city and its unique "DNA".

Formation of the concept of interaction of the parties involved corresponds to the planning stage. While the stage of defining the scope of the project provides an analytical basis and a comprehensive rationale for the regeneration project, a long-term vision and context is established at the planning stage. When forming a vision of the project, it is necessary to take into account the inevitable changes and risks of different phases of market cycles. Effective structured planning allows balancing interaction between the public, private and public sectors. The planning system combines a long-term vision with a clear regulation process. This approach allows us to give the necessary confidence to invest and take risks to the private sector, and also convinces the public that social goals will be achieved, and not solely subject to market dictates. At the planning stage, all the major factors of the regeneration project, including land, community interests and environmental problems, must be taken into account.

Stimulation of private financing corresponds to the stage of budget allocation. Whether the initiative to renovate cities by the public or private sector has been proposed affects the types of financing instruments that can be made available to its lead sponsor. Large-scale projects for the renovation of cities are complex and require significant resources (Chulkov, Gazaryan, Kuzina, 2014). Not all cities have the resources to finance the costs of such major initiatives in full. Partnership with the private sector is significant to cover costs, as well as to distribute risks and to balance technical capabilities. Many factors affect the methods used to finance initiatives to renovate cities. The most important factor is the legal and institutional context with regard to control over financial management, in particular the ability to raise and distribute income. To finance the renovation of cities, there are two groups of instruments: financial instruments and regulatory instruments. Financial instruments include direct financing of the regeneration project. The regulatory tools use the powers of the city to stimulate the participation of the private sector.

An example of this type of instrument is tax and non-tax incentives, zoning, land use rules and transfer of development rights (Shul'zhenko, Kievskiy, Volkov, 2016).

In this article, the aim of the research is to estimate the renovation impact on Moscow city budget and developers' financials as the key objective of the research. During the analysis, the author forecasted potential scenario of Moscow real estate market development assuming renovation programm will be realized. Forecasted results are based on standard DCF model with the number of assumptions (renovation ratio etc.). It is also worth noting, that before the current research there was no complex and complicated finacial forecast of real estate developer's finances and potential benefits for the Moscow budget.

\section{Methodology of research and materials}

Evolution from ideas to action refers to the stage of realization. The implementation phase involves the implementation of the concept of long-term changes in financial, contractual and institutional relations between the public and private sectors. This stage includes the formation of a stable 
organizational structure of the project, involves the development of sound contracts to translate the concept into a material partnership between the public and private sectors. Public administration can be the most important factor in the implementation phase. Since the renovation process is long-term, it involves the transformation of the usual urban processes, which entails certain risks, the leadership of the city authorities is important for managing the process of change, with a view to consolidating society, so that all interested parties feel involved in the process, understand its significance for the future of the city.

Another important indicator of success at the implementation stage is the compliance with the terms of the project, the expected project cycle and milestones, taking into account the uncertainty factor (Gusakova, Pavlov, 2016). Then follows the phasing and breakdown of a large project into manageble components.

Also an essential element of the implementation mechanism is the definition of the optimal institutional structure for the conduct of the project and the distribution of the powers of the various actors. This affects the structure of contracts, the transfer of services and the sustainability of the project.

Projects for the renovation of the city are aimed at achieving an optimal combination of residential, social and commercial functions (Kievskiy, Kievskaya, Mareev, 2015). The effects of complex renovation can be divided into two groups: non-economic and economic.

The group of non-economic effects includes:

- Reducing the degree of deterioration of residential development;

- Improvement of housing conditions of the population;

- Improvement of social infrastructure in the neighborhoods in which renovations are taking place;

- Improved energy efficiency. Renovation quarters are laying new standards of quality: reducing the thermal conductivity of walls, roofs, the use of effective ventilation principles, the use of new designs of balconies and double-glazed windows.

As an economic effect, there is a flow of cash (net funds). The flow of real money is defined as the difference between the inflow and outflow of cash in each period of the project. To analyze the effectiveness of various scenarios of the project for the renovation of built-up areas, the following main criteria are used:

- Net present value (or Net present value, NPV) is an indicator that represents the difference between all the cash inflows and outflows that are given to the current time point (the moment when the investment project was evaluated). NPV shows the amount of cash that the investor expects to receive from the project, after the cash inflows have paid off its initial investment costs and periodic cash outflows associated with the project.

- Internal rate of return (IRR) - the interest rate at which the net present value (net present value NPV) is 0 . The criterion with which to compare the IRR is the opportunity cost of capital for these investments (for example, rates on bank deposits as an alternative way of investing funds).

Consider the impact of key parameters of the renovation project on economic indicators.

We will accept for evaluation the following approximate parameters (key and variable) of renovation programs in Moscow (see table 1).

Table 1

Key parameters of renovation

\begin{tabular}{|l|c|c|}
\hline \multicolumn{1}{|c|}{ Item } & Unit & Amount \\
\hline Renovation ratio & $\mathrm{x}$ & 2.30 \\
\hline Resettlement ratio & $\mathrm{x}$ & 1.30 \\
\hline Construction cost & $\mathrm{RUB} / \mathrm{sq} \mathrm{m}$ & 65000 \\
\hline Construction period & Years & 1 \\
\hline Sale price for apartments & $\mathrm{RUB} / \mathrm{sq} \mathrm{m}$ & 160000 \\
\hline
\end{tabular}

Source: Author estimates, Rosstat, Government of Moscow

\section{Discussion and results}

Renovation program will have outcomes in two fields: social and economic (Tikhomirov et al, 2015). It is too complicated to analyze whole range of social effects due to many factors, which influence this area. However, economic results of this program can be estimated more properly due to limited 
range of general assumptions. Please see below the outputs of financial overview of the Moscow renovation program.

Table 2 demonstrates key operating and financial outcomes of the program. Main operating indicators are volumes of demolition (previously declared by Moscow authorities), construction (preliminary numbers, subject for approvals for each project and Moscow district) and resettlement (previously declared by Moscow authorities).

Assumptions related to construction costs and sales prices are based on current and forecasted market conditions.

Due to fixed positive margin between construction costs and proceeds from sale, the only factor that has strong impact on financial results of the program is the construction volume.

Calculations indicate that renovation ratio of less than 2.0x leads to non-significant financial results. Due to developers have to reimburse demolished volume plus 30\% premium for free they need to have more additional volume available for sale on market terms. That is why Moscow authorities have to accept high renovation ratio to cover all expenses related to the program and arise addition inflows in the budget via income and property tax related to new property volumes.

Calculations provided below prove that renovation program leads to positive economic effects. The main idea of the calculation below is that developer's payback and financial results (as well as government budget) depend on renovation ratio. That means that if the renovation ratio will be estimated less than 2 points, than the renovation project is economically unprofitable and money from developed spaces for sale will not meet the expences for construction, because a part of the developed spaces will go free of charge.

Varying the key parameters has an impact on social outcomes and the calculation of the project economy. Social outcomes depend on the resettlement ratio and the renovation factor.

\section{Conclusions and proposals}

The process of changing the urban space and the appearance of residential areas of Moscow is one of the main achievements of today's urban policy. The work is conducted not with appearance, but with the environment of the districts themselves. Comfortable living environment implies a clear structure of residential education with the delimitation of private and public areas and the placement of all elements of the residential environment within a clear planning structure. Private and public spaces ensure the interconnection of all elements of the structure of the residential area (urban block, block and microdistrict) and increase the efficiency of the use of the territories by streamlining the placement of all elements of the residential environment.

Well-located and properly maintained housing built on a renovation program, will solve the most important social problems of the city.

Due to the fact, that within the framework of renovation, housing will be built where people will have access to jobs and priority services, and provided effective management and services are provided, it is possible to achieve an increase in housing capitalization for citizens who are included in the program.

Also, the deployment in Moscow of a program for large-scale renovation of residential areas, involving significant amounts of new construction, will give a new impetus to the development of the construction industry as a whole, as well as related economic sectors (including machine building). 
Table 2

Key performance indicators of Moscow renovation program

\begin{tabular}{|c|c|c|c|c|c|c|c|c|c|c|c|c|c|c|c|c|c|c|}
\hline Item & Unit & Total & 2018 & 2019 & 2020 & 2021 & 2022 & 2023 & 2024 & 2025 & 2026 & 2027 & 2028 & 2029 & 2030 & 2031 & 2032 & 2033 \\
\hline \multicolumn{19}{|l|}{ Operating metrics } \\
\hline Demolition volume & $\mathrm{m} \mathrm{sqm}$ & 18 & 1.2 & 1.2 & 1.2 & 1.2 & 1.2 & 1.2 & 1.2 & 1.2 & 1.2 & 1.2 & 1.2 & 1.2 & 1.2 & 1.2 & 1.2 & \\
\hline Cumulative & $\mathrm{m} \mathrm{sqm}$ & & 1.2 & 2.4 & 3.6 & 4.8 & 6.0 & 7.2 & 8.4 & 9.6 & 10.8 & 12.0 & 13.2 & 14.4 & 15.6 & 16.8 & 18.0 & 18.0 \\
\hline Construction volume & $\mathrm{m} \mathrm{sqm}$ & 41 & 0.0 & 2.8 & 2.8 & 2.8 & 2.8 & 2.8 & 2.8 & 2.8 & 2.8 & 2.8 & 2.8 & 2.8 & 2.8 & 2.8 & 2.8 & 2.8 \\
\hline Resettlement volume & $\mathrm{m} \mathrm{sqm}$ & 23 & 0.0 & 1.6 & 1.6 & 1.6 & 1.6 & 1.6 & 1.6 & 1.6 & 1.6 & 1.6 & 1.6 & 1.6 & 1.6 & 1.6 & 1.6 & 1.6 \\
\hline Cumulative & m sqm & & 0.0 & 1.6 & 3.1 & 4.7 & 6.2 & 7.8 & 9.4 & 10.9 & 12.5 & 14.0 & 15.6 & 17.2 & 18.7 & 20.3 & 21.8 & 23.4 \\
\hline Sales volume & $\mathrm{m} \mathrm{sqm}$ & 18 & 0.0 & 1.2 & 1.2 & 1.2 & 1.2 & 1.2 & 1.2 & 1.2 & 1.2 & 1.2 & 1.2 & 1.2 & 1.2 & 1.2 & 1.2 & 1.2 \\
\hline Cumulative & $\mathrm{m} \mathrm{sqm}$ & & 0.0 & 1.2 & 2.4 & 3.6 & 4.8 & 6.0 & 7.2 & 8.4 & 9.6 & 10.8 & 12.0 & 13.2 & 14.4 & 15.6 & 16.8 & 18.0 \\
\hline \multicolumn{19}{|l|}{ Developer economics } \\
\hline Revenue & RUBbn & 3998 & 0 & 200 & 208 & 216 & 225 & 234 & 243 & 253 & 263 & 273 & 284 & 296 & 307 & 320 & 332 & 346 \\
\hline Sale price & kRUB/sqm & & 160 & 166 & 173 & 180 & 187 & 195 & 202 & 211 & 219 & 228 & 237 & 246 & 256 & 266 & 277 & 288 \\
\hline CPI RUS & $\%$ & & & $4 \%$ & $4 \%$ & $4 \%$ & $4 \%$ & $4 \%$ & $4 \%$ & $4 \%$ & $4 \%$ & $4 \%$ & $4 \%$ & $4 \%$ & $4 \%$ & $4 \%$ & $4 \%$ & $4 \%$ \\
\hline Expenses & RUBbn & 3437 & 0 & 185 & 190 & 196 & 202 & 208 & 214 & 221 & 227 & 234 & 241 & 248 & 256 & 263 & 271 & 279 \\
\hline Construction cost & kRUB/sqm & & 65 & 67 & 69 & 71 & 73 & 75 & 78 & 80 & 82 & 85 & 87 & 90 & 93 & 95 & 98 & 101 \\
\hline PPI RUS & $\%$ & & & $3 \%$ & $3 \%$ & $3 \%$ & $3 \%$ & $3 \%$ & $3 \%$ & $3 \%$ & $3 \%$ & $3 \%$ & $3 \%$ & $3 \%$ & $3 \%$ & $3 \%$ & $3 \%$ & $3 \%$ \\
\hline Profit before tax & RUBbn & 562 & 0 & 15 & 17 & 20 & 23 & 26 & 29 & 32 & 36 & 39 & 43 & 47 & 52 & 56 & 61 & 66 \\
\hline Income tax & RUBbn & 112 & 0 & 3 & 3 & 4 & 5 & 5 & 6 & 6 & 7 & 8 & 9 & 9 & 10 & 11 & 12 & 13 \\
\hline Tax rate & $\%$ & & $20 \%$ & $20 \%$ & $20 \%$ & $20 \%$ & $20 \%$ & $20 \%$ & $20 \%$ & $20 \%$ & $20 \%$ & $20 \%$ & $20 \%$ & $20 \%$ & $20 \%$ & $20 \%$ & $20 \%$ & $20 \%$ \\
\hline Net income & RUBbn & 449 & 0 & 12 & 14 & 16 & 18 & 20 & 23 & 26 & 28 & 31 & 34 & 38 & 41 & 45 & 49 & 53 \\
\hline $\begin{array}{l}\text { Additions to } \\
\text { Moscow budget }\end{array}$ & RUBbn & 120 & 0 & 3 & 4 & 4 & 5 & 6 & 6 & 7 & 8 & 8 & 9 & 10 & 11 & 12 & 13 & 14 \\
\hline $\begin{array}{l}\text { Income tax from } \\
\text { developers }\end{array}$ & RUBbn & 112 & 0 & 3 & 3 & 4 & 5 & 5 & 6 & 6 & 7 & 8 & 9 & 9 & 10 & 11 & 12 & 13 \\
\hline $\begin{array}{l}\text { Property tax from } \\
\text { additional area }\end{array}$ & RUBbn & 8 & & 0 & 0 & 0 & 0 & 0 & 0 & 0 & 1 & 1 & 1 & 1 & 1 & 1 & 1 & 1 \\
\hline Additional volume & $\mathrm{m} \mathrm{sqm}$ & & & 2 & 2 & 2 & 2 & 2 & 2 & 2 & 2 & 2 & 2 & 2 & 2 & 2 & 2 & 2 \\
\hline Property tax rate & $\%$ & & 0.15 & 0.15 & 0.15 & 0.15 & 0.15 & 0.15 & 0.15 & 0.15 & 0.15 & 0.15 & 0.15 & 0.15 & 0.15 & 0.15 & 0.15 & 0.15 \\
\hline
\end{tabular}

Source: Author estimates 


\section{References}

1. Woetzel J., Ram S., Mischke J., Garemo N., Sankhe S. (2014) A blueprint for addressing the global affordable housing challenge. McKinsey Global Institute, 30p.

2. Chulkov V. O., Gazaryan R. R., Kuzina O. V. (2014) Bazovyi cikl reorganizacii. Sbornik: Innovacii v otraslyakh narodnogo khozyastva kak faktor reshenia socialno-ekonomicheskikh problem sovremennosti, Sbornik dokladov I materialov practicheskoi konferencii, pp. 82-94 (in Russian).

3. Kievskiy L. V., Kievskaya R. L., Mareev Yu. A. (2015) Mezhdunarodnye reitingi gorodov kak kriterii gradostroitelnogo razvitia, Jilishnoe stroitelstvo, № 12, pp. 3-8 (in Russian).

4. Tikhomirov S. A., Kievskiy L. V., Kuleshova E. I., Kostin A. V., Sergeev A. S. (2015) Modelirovanie gradostroitelnogo processa, Promyshlennoe i grazhdanskoe stroitelstvo, № 9, pp. 51-55 (in Russian).

5. Gusakova E., Pavlov A. (2016) Osnovy organizacii i upravleniya v stroitelstve. Izdatelstvo Yurait, Moskva, 320 p (in Russian).

6. Kievskiy I. L., Grishutin I. B., Kievskiy L. V. (2017) Rassredotochennoe pereustroistvo kvartalov (predproektny etap), Jilishnoe stroitelstvo, № 1-2, pp. 23-28 (in Russian).

7. Barbosa F., Woetzel J., Mischke J., Ribeirinho M.J., Sridhar M., Parsons M., Bertram N., Brown S. (2017) Reinventing construction: a route to higher productivity. McKinsey Global Institute, 20p.

8. Shul'zhenko S. N., Kievskiy L. V., Volkov A. A. (2016) Sovershenstvovanie metodiki ocenki urovnya organizacionnoi podgotovki territorii sosredotochennogo stroitelstva, Vestnik MGSU, № 3, pp. 135-143 (in Russian).

\section{Information about author}

Elizaveta Kheifetz, Master of Economics, PhD-candidate, Financial University under the Government of the Russian Federation. Moscow, +7 90577798 07, liza.kheifetz@ yandex.ru . Fields of interest - urban economics, cadastral management, real estate valuation 